\title{
Exploration about Afro-American Literature
}

\author{
Zhenzhen Zhang, Hong Yang \\ College of Foreign Languages, Hebei University of Technology, Tianjin, 300401, China
}

Keywords: America, black literature, artistic creation mode

\begin{abstract}
The developmental history of Afro-American literature is a piece of history for Afro-American to seek for acceptance and recognition towards the world of white people and to acquire respect. By recognizing and exploring Afro-American literature, it is able to discover the essence and soul included in Afro-American literature, and is also able to better understand American literature. This paper has introduced the origin of Afro-American literature, described the development process of Afro-American literature, and discussed the unique artistic creation mode of Afro-American literature.

America is a multicultural nation permeated and integrated by each nation. In this culture melting pot, it has created a lot of unique and distinctive cultures, and black culture is undoubtedly one of the typical cultural forms in them. This requires us to regard time as a clue and go deep into the historical development process of Afro-American literature to examine the evolution process of black culture, so that to grasp the whole development context more clearly. From the development process of Afro-American literature, it is possible to deeply understand the strong will of the black race, and to feel their strong feelings to pursue freedom more closely.
\end{abstract}

\section{Origin of Afro-American Literature}

Afro-American's native place was Africa, who came to American with doubts from the beginning. At that time, they had ambiguous futures, which could be said that their life and death were unpredictable and their identities were not clear. This uniqueness of black people determined that they were very thirst for knowledge from the beginning and imaged a better future, which was the eternal theme of Afro-American literature kept for centuries, and at the same time was the unique ethnic spirit demonstrated in the survival and development process of Afro-Americans. Afro-American literature first appeared at the beginning of the nineteenth century, and when African black people came to American continent, it had buried the development seed of black literature in this new piece of land. At the beginning of the black literature, the main forms were anthems, folk songs and secular songs in the oral singing, among which the one most reflected the real inner world of black people was anthem. This was because it expressed a strong melancholy of black people under very tragic situation. Early nineteenth century was the transition period of Afro-American literature from original oral literature to creation literature. In this period, the representative works of poetries are Jupiter's Quiet Night Thoughts - the Savior Jesus Christ and Phyllis Wheatley's Religion and Moral Poetry Collection, whose themes mainly reflected were to expose and denounce the extremely brutal apartheid policy of white people, and to describe the damage of ignorant and backward to the soul of blacks with sad brush strokes, so ignorance became an enduring and profound topic in Afro-American literature. In this period, the relatively famous black writers were Josiah Henson, Linda and Douglas, etc. Their works strongly expressed the good wishes of blacks to pursue freedom and courage to get rid of the constraints, so that to obtain the liberation and win happy lives.

\section{Development History of Afro-American Literature}

The theme of Afro-American literature after nineteenth century was mainly to explore the origin of them, expose the brutal slavery secret and ask for liberation and freedom. This theme continued to the first half of the last century, and gradually developed into explore the road for the blacks to develop and improve the living conditions of blacks. Especially since the American Civil Was, a large number of well-known Afro-American writers such as Paul Lawrence Dunbar, Du Bois deeply 
exposed the brutal destruction of racial discrimination for blacks in their literary works. For example, American folk song Slavery and Freedom sharply pointed out the substance that Afro-Americans got the freedom after the Civil War. Dunbar was the first Afro-American professional writer who could not only write poetries, but also create short stories and full-length novels, whose well-known works included Ode to Ethiopia, Heroes Nobody Sings, and Black Warrior, etc. Although he was a poet greatly concerned about the destiny of the nation and the sufferings, in order to get success in the world of white dominance, he had to create some so-called works catering to the taste of readers one-sidedly. This was actually the root of intense contradictions and pains in his inner heart. This tragedy of Dunbar proved the great destruction of racial discrimination to Afro-American literature.

Chesnutt was recognized as the first Afro-American writer to have prominent success in creating short stories. His short story Witch was wrote by taking full use of black dialects, which spoke out the great persecution of slavery towards black people and the misfortunes suffered by black slaves from the mouth of a black old gardener. His another short story His Wife in His Youth mainly described the love tragedy of blacks under the context of racism. And the full-length novel The Marrow of Tradition was his representative work, which mainly regarded the terrible violence of bloody massacre to local blacks appeared in the selection carried out in North Carolina Wilmington in 1898 as the main background, and it had a good practical significance. This novel made a quite profound revelation for the Southern racial discrimination after Civil War. The difference of Chesnutt from Dunbar was that he failed to surrender to white society completely and failed to beautify the relations between various nations by whitewashing the reality in his own creations, but revealed various oppressions and racial discrimination in current society by using the critical spirit of realism. This was the most success of his novels in the two aspects of ideology and art. Precisely because of this, a part of black critics called him as the leader of Afro-American literary realism.

Du Bois was a writer with most influential works in the black writers in that period, whose most important works were collection of essays Soul of Blacks and biographies John Brown. On one hand, he deeply studied the African problems and various race relations in the America, on the other hand, actively participated in the liberation movements of blacks. In 1905, he launched the very famous Niagara Movement to strongly oppose the so-called surrender tendencies among the black liberation movements, which required that black people is able to enjoy all civil rights and social welfare, and had a targeted struggle with the Tuskegee Movement led by Booker T. Washington. Du Bois not only had a very brilliant achievement in literature creation, but also was the most influential black intellectual and spiritual leader in twentieth century of America. In his works Souls of Blacks, he predicted that the main problem in the 20th century was the color lines under racial discrimination.

Black liberation is not a simple paper of Emancipation Proclamation can be immediately solved; it is a very long process, so it needs to be addressed incrementally. Although after entering into the 20th century, the economic and political status of Afro-Americans had experienced significant changes, however, social life was not completely opened to the majority of blacks. Complete liberation of black people still needed further efforts. Alai Locke's New Negro Comments advocated blacks should have self-esteem and self-reliance. Black writer Langston Hughes in his free verse poem When I was growing up also advocated that black people should rely on their own strength to break through the blockade of apartheid to achieve their dreams. Writer Richard Wright's Uncle Tom's Children and Black Children fondly described the economic plight, mental depression and psychological fear of black people. If you said Langston Hughes's poems were written for black fellow citizens, the works of Richard Wright were clearly written for the white people. Because when he exposing the darkness of society, he did not incite racial hatred, but was committed to enhancing mutual understanding and communication between different races and exploring the new ways for black people, so the mainstream of Afro-American literature in 20th century was to call the black people to have self-esteem, self-reliance and self-confidence, so that to reveal the various racial issues remained in the society, to get the understanding from white people, and to jointly solve the deep-seated problems of blacks. 
In the second half of the last century, the Afro-American cultural circle also launched the movements aiming at achieving the cultural freedom of Afro-Americans. A part of black researchers proposed to re-reverse the reversed history, which mainly included the re-evaluation of slavery. For example, as the important part of the American black rights movement, the scale and influence of the black literary movement in 1964 had exceeded the Harlem Renaissance launched in the 1920s. This campaign was committed to changing the situation and status of Afro-Americans, changing the image of blacks in the American literary arts, which reflected the spirit of blacks in the 1960s. Fuller published Move towards Afro-American Literature in 1968, which combined the black aesthetic with black rights movements. To fight for unity within the black community, black people had to get back and respect the cultural essence of its own uniqueness, which needed a Negritude to get rid of the influence of white people's mainstream cultural values. From the end of the sixties of the last century to the end of the eighties of the last century, it produced a large number of new works imitating the previous slave documentary literature, which was called new slave documentary literature by the black researcher Bernard W Bell. The famous black women writer Morrison created Beloved, which became her representative. This period was also the dazzling period for Afro-American women writers. As the first Afro-American writer to win the Nobel Prize in literature, Toni Morrison had been globally recognized as one of today's most famous novelists. After entering into the nineties of the last century, the black literature as an important part of black culture, had been deeply integrated into American culture, and the black literature had developed towards the trend of diversification, which played an important role in promoting the development of America’s diversification.

\section{Unique Artistic Creation Mode of Afro-American Literature}

Since the Middle of the last century, the World War II ended, a large number of blacks began to flow into cities. Under the tremendous encouragement of continuous success of civil rights movements launched in Asia, Africa and Latin America, they carried out vast and mighty black civil rights movements, and used all kinds of ways to oppose the unfair treatments, no matter violent or non-violent. Black people from various states used the practical actions to boycott all kinds of unjust laws and policies to fight for their legal rights, for example, the movements launched aiming at the racial discrimination encountered on the bus, and the protest actions led by Martin Luther King, such as sit-in demonstrations. In the Afro-American writer Rosa Parks' work Struggle Sisters - Civil Rights and the Afro-American Women in Black Civil Rights Movements, it mentioned her own experience on the bus. In her book, she said that she also deeply knew that she was likely to be driven off, or brutally treated by the white police, but she still chose to stay bravely and fight for his own reasonable rights and interests. If a nation wants to be united, it must have their own unique national culture and national spirit. We can say that the experiences of Afro-Americans dare to pursue independence and independent human rights, actually, is also the important process to pursue the independence culture. Afro-American literature theorist Hoyt Fuller once pointed that if we want the blacks get together, they must find out the cultural root praised highly by the whole nation. After the last 1950s, the focus of Afro-American literature began to change from improving their political and economic right to actively exploring the personal independence and ethic culture, making great efforts to create black's own unique literature and art mode. Blacks trafficked to the American continent always fantasized that one day they could return to their hometown - Africa. They were strongly yearn for freedom and hoped to fly in the sky freely and unfetteredly like birds, and also wanted to be able to get the full liberation of the spirit and the body. This idea can be reflected in the Songs of Solomon written by the famous Afro-American writer Toni Morrison. This work used the folk songs which were good at by the Afro-Americans, and repeatedly interpret the ancient Greek mythologies. In the mythologies, in order to leave the Crete, the architect's son Jil Kaas tried to fly by fixing the bird feathers on his arms with wax, but later due to being excessively intoxicated with the strong joyfulness, the max was melted by the high temperature of the sun, causing the tragedy of falling into the ocean and the death. However, the focus of novels was that in order to escape from enslavement life, Solomon took his little son Jack to fly back to Africa. But on 
their way, Jack was very unfortunate to fell to the ground and stayed on the American land forever. Fly and aircraft both referred to the strong desire of freedom for blacks. Even if they needed to pay their precious lives, they would never give up the strong pursuit of freedom.

\section{Conclusion}

In general, Afro-American literature faithfully has recorded the indomitable spirit of Afro-American people to squeeze into the white mainstream society with self-reliance, so that to show their own unique styles. Literature is the most direct and convenient form to express Afro-Americans' own ideas, and it is applied to the extreme situation. Whether the Afro-American traditional literature passed down and preserved from mouth to mouth, or the Afro-American literature recorded in writing form, it is filled with the tough characters of Afro-Americans. Although they are far away from their homeland, the warm blood flowed in their bodies makes their national consciousness to be continuously inspired and waken up. The Afro-American writers explore in depth the root of the nation in a very difficult environment, who praise blacks through poetries, satirize the status quo through novels, and express the pursuit of freedom for blacks through prose, so that to obtain the spiritual peacefulness.

\section{References}

[1] Zhang Jun, A Study of "Three Flowering Periods" in the Development of African American Literature [J], Contemporary Foreign Literature, 2008 (1)

[2] Ma Haiying, The New Negro Cultural Movement in America and its Effect [J], Journal of Henan Normal University (Philosophy and Social Sciences), 2008 (3).

[3] Gong Ling, Pursue the Root of Black Culture - Interpreting Toni Morrison's Song of Solomon and Beloved [J], Social Sciences Hunan, 2012 (6).

[4] Huang Yazhen, Flourishing and development of Afro-American Literature after World War II [J], Overseas English, 2010 (11).

Fan Peng, Identity-building in African American Literature [J], Social Sciences Journal of Colleges of Shanxi, 2011 (3). 